\title{
The Effect of Maintenance Works on Ichthyofauna in the Context of Hydrochemical Conditions of Small Watercourses of Central and North-Western Poland
}

\author{
Adam Brysiewicz' ${ }^{1 *}$ Przemysław Czerniejewski \\ 1 Institute of Technology and Life Sciences, Falenty, al. Hrabska 3, 05-090 Raszyn, Poland \\ 2 West Pomeranian University of Technology Szczecin, Department of Fisheries Management, Faculty of Food \\ Sciences and Fisheries, Kazimierza Królewicza Street 4, 71-550 Szczecin, Poland \\ * Corresponding author's e-mail: a.brysiewicz@itp.edu.pl
}

\begin{abstract}
The studies were conducted in the summers of 2017 and 2018 on three watercourses in Central and North-Western Poland, the where maintenance works involving disposal of sediment and silt were performed in the autumn of 2017. Monitoring of the ichthyofauna in the Rurzyca River and the Tywa River before (year 2017) and after the maintenance works (year 2018) indicated a decrease in the number of species. Altogether, 23 fish species were caught in all the watercourses. Out of these, 12 species were not recorded after the studied rivers had been dredged. A slight decrease in the number of fish species was observed in each studied river after the maintenance works. The values of physicochemical parameters obtained for each watercourse indicate a low quality of the waters. After silt had been removed from the watercourses, lower $\mathrm{N}_{-} \mathrm{NO}_{3}^{-}$values were observed at most research

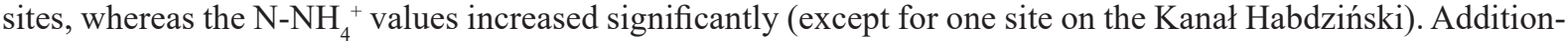
ally, high volumes of $\mathrm{P}_{-} \mathrm{PO}_{4}{ }^{3-}$ were observed (except for sites 2 and 3 on the Kanał Habdziński and site 2 on the Rurzyca River). Maintenance works performed on small watercourses have a negative impact on the quality of waters and a less significant impact on the number of fish and biodiversity. This appears to be connected with migration of fish in the river during the maintenance works and avoidance of the consequent unfavourable conditions to gradually return to their habitats afterwards.
\end{abstract}

Keywords: dredging, watercourse, fish, habitat preferences, biodiversity

\section{INTRODUCTION}

Flowing waters constitute Ecosystems exposed to permanent and frequent natural and anthropogenic changes are. Seasonal high water levels and periods of low water levels associated with low river flows (especially in the summer and early autumn) affect the morphological conditions of a river bed, the flora and fauna (Kazanowska 2012; Cavailléa et al., 2013). Aside from the climatic factors, intensification of agriculture also plays a significant role. The runoffs of biogenes and municipal sewage into rivers contribute to the process of eutrophication (Luek and Rasmussen 2017; Wojciechowska et al., 2019). Anthropogenic watercourses with unnaturally increased physical and chemical parameters of water can disturb reproduction, embryonic development, metamorphosis and breeding, consequently leading to eradication of numerous water organisms (Haidekker and Hering, 2008). High eutrophication of watercourses very often results in significant sedimentation, but also complete overgrowth with macrophytes, which leads to slower water flow, and in extreme cases, even to the desiccation of a watercourse. The lack of water passability may also result in the flooding of the neighbouring areas. Therefore, it is a duty of the owner of the waters to maintain them, but also to guarantee the achievement of environmental aims. Typical maintenance works include silt disposal through the removal of excess sediments, removal of rushes from the banks as well as from the riverbed and elimination of obstacles 
such as fallen trees or branches, in order to increase water flow in the river channel. Recently, calls for both the need to intensify maintenance works and opinions of a strongly degrading effect of such works and regulation of river ecosystems have appeared (Bondar-Nowakowska and Hachol, 2015). It is presumed that silt removal may have a significant effect on the population of river ichthyofauna (Stammler et al., 2008; WardCampbell et al., 2017). Much is known about the changes in the hydrology of the stream induced by drainage, but the effect of maintenance works in watercourses on biodiversity has not yet been scrutinised thoroughly enough to find the effective methods for the mitigation of changes in an ecosystem (Louhi et al., 2010).

Due to their small area and length, small natural streams do not arouse interest from the fishing and angling industry and, as confirmed by research, these are a habitat for numerous fish species (Meyer et al., 2007) which might be sensitive to prolonged periods of low water flow in modified watercourses in combination with seasonal desiccation (Jutila et al., 2001) and increased sedimentation of watercourses (Kemp et al., 2011). Small watercourses located in agricultural areas and even draining systems might constitute important habitats for fish and, in some cases, for the endangered ichthyofauna species (Montgomery et al., 2018). Due to the significant effect on the hydrochemical water pollution and fish habitats in the main watercourse, small watercourses may constitute an interesting object of studies for fish population ecology.

Our studies assessed the effect of silt removal in selected watercourses on the condition and population of ichthyofauna and changes in the hydrochemical and environmental parameters resulting from maintenance works that had been performed.

\section{MATERIAL AND METHODS}

The studies were conducted on three selected watercourses located in North-Western Poland (the Tywa River and the Rurzyca River) and in Central Poland (Kanał Habdziński) (Fig. 1). Three research sites were selected on each river. The rivers were selected for studies because the maintenance works involving silt removal had been scheduled for them. The studies were conducted

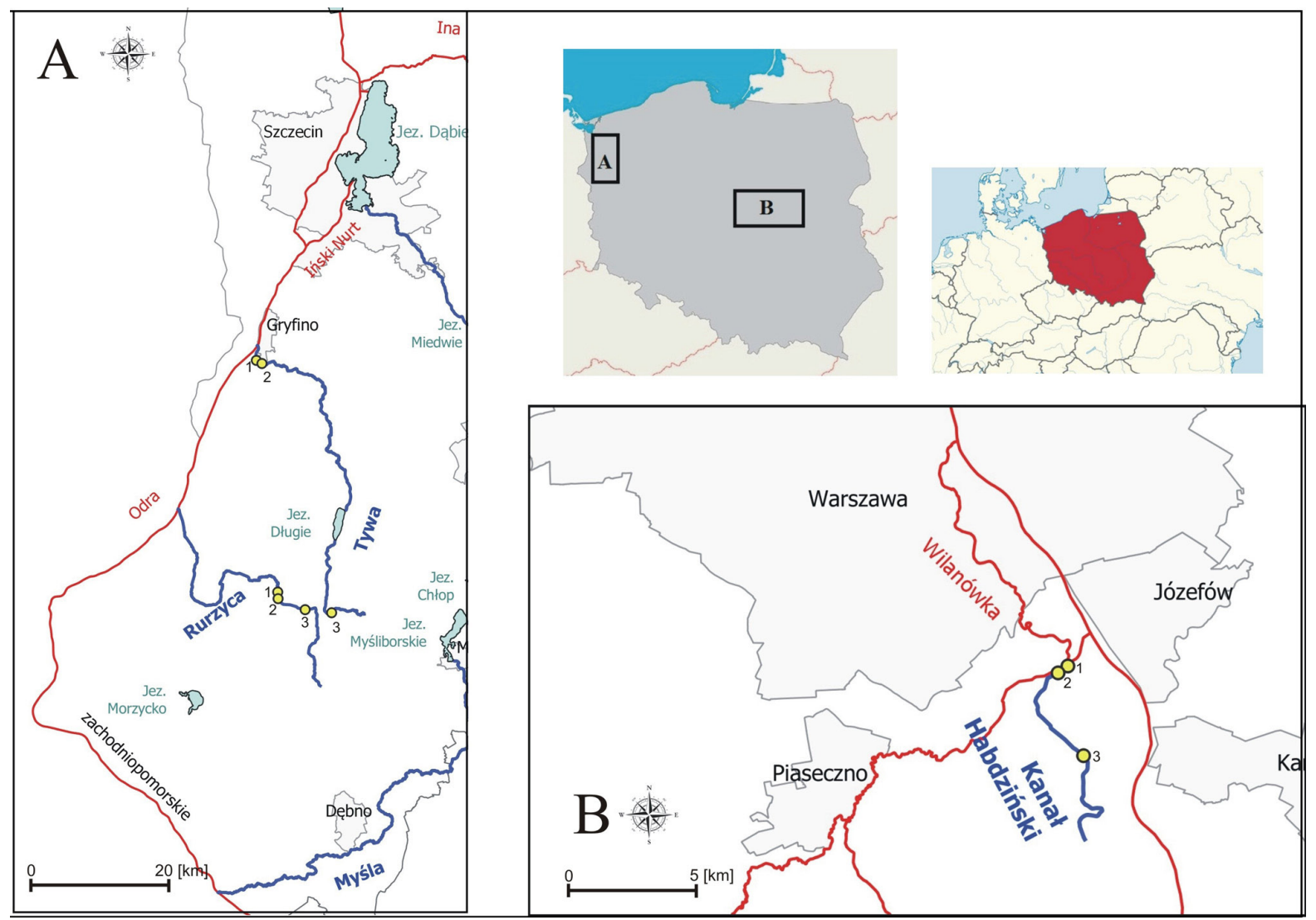

Fig. 1. Location of research sites on the Tywa River and the Rurzyca River (A) and on the Kanał Habdziński (B) 
in the summers of 2017 and 2018. Such selection resulted from the fact that in late autumn of 2017 (Sept.-Nov.), maintenance works were performed at each research site, so the authors were able to assess the changes before and after the works.

The fish were caught using Electric Fishing Device Type ELT 60 II GI. The following norms were observed during the fishing: CEN EN 14011 2003 and PN-EN 14011 2006, because obtaining reliable information on the distribution and domination of species in rivers requires electric fishing, taking into consideration the unique nature of a given watercourse. Fishing at each site was performed by wading against the tide at 100-metre sections. The fish caught at each site were divided by species and the number of specimens of each species was determined.

In order to assess the environmental conditions, temperature, electrolytic conductivity (EC) and $\mathrm{pH}$ were measured using a $\mathrm{HACH}$ multiparameter and the volume of dissolved oxygen was measured using a WTW Multi 3400 meter with a Cellon 323 oxygen probe. Measurement of water velocity was performed using a SENSA $\mathrm{RC} 2$ electromagnetic meter equipped with an RV2 probe manufactured by Quantum Dynamics Ltd. Aqua Data Services Division. Moreover, the depth, sedimentation and macrophyte overgrowth of the river were measured at each research site.

Simultaneously, water samples were collected from the studied rivers. The samples were collected in accordance with the current norms. The concentrations of $\mathrm{N}_{-} \mathrm{NO}_{3}{ }^{-}, \mathrm{N}-\mathrm{NH}_{4}{ }^{+}$and $\mathrm{P}-\mathrm{PO}_{4}{ }^{3-}$ in the waters were determined as well. The concentrations of nitrogen forms and phosphates were determined in the Research Laboratory of Environmental Chemistry of the Institute of Technology and Life Sciences in Falenty using the colorimetric method by means of a Skalar automated continuous flow analyser.

The differences in the number of species and the number of fish between the period before the maintenance works and the period after the works were evaluated using a chi-squared test ( $\chi 2$ test). Principal Component Analysis (PCA) was also used to reduce the multidimensional data sets of all the elements to lower dimensions, thus simplifying the presentation and interpretation of data. The differences were considered significant at $\mathrm{p}<0.05$. The statistical analysis was performed using Statistica 12.0 software.

\section{RESULTS AND DISCUSSION}

\section{Description of environmental conditions and physicochemical parameters of small watercourses}

Monitoring of the environmental conditions on the selected rivers indicated diverse water flow, depth, sedimentation and macrophyte overgrowth (Table 2). Increased water flow was observed in the studied rivers in year 2018. The effect appears to be connected with increased water passability, being the result of the maintenance works performed on the watercourses. A lower water level was also observed, which might be justified by dry year 2018 and little precipitation in comparison to year 2017.

As far as the riverbed assessment is concerned, the lowest sedimentation was observed in the Tywa River (Table 1). Except for site 3 on the studied river, the situation changed insignificantly despite the maintenance works. Additionally, sedimentation of the Kanał Habdziński was observed relatively soon where a sandy and hardened bottom was only observed at one site. A different situation was observed on the Rurzyca River, where small or trace amounts of silt were observed on the riverbed (Table 1).

Moreover, extremely rapid overgrowth with water plants was observed on the Kanał Habdziński after the maintenance works (Table 1).

The water samples from each research site were characterised by significant diversification of physicochemical parameters (Table 2). The PCA demonstrated the presence of separate groups of sites for each river (Fig. 2). The first component explains $37.50 \%$ of total variance, whereas the second component explains $27.09 \%$ of total variance.

The values of physicochemical parameters obtained for each watercourse indicate a low quality of their waters. High electrical conductivity $(E C>700)$ was observed at three research sites (Tywa 1 and Rurzyca 2 and 3) and the oxygen content exceeding $5 \mathrm{mg} \cdot \mathrm{dm}^{-3}$ was only observed at sites 1 and 2 on the Tywa River and at site 2 on the Rurzyca River. Temporarily, the water concentration of $\mathrm{N}^{-\mathrm{NO}_{3}}{ }_{3}^{-}$exceeded $7 \mathrm{mg} \cdot \mathrm{dm}^{-3}$ at five research sites and the concentration $\mathrm{N}_{-} \mathrm{NH}_{4}^{+}$exceeding $1 \mathrm{mg} \cdot \mathrm{dm}^{3}$ was observed at two sites (Table 2). Moreover, the concentration of $\mathrm{P}_{-} \mathrm{PO}_{4}{ }^{3-}$ was relatively high and at three sites (Rurzyca 1 and 3 and Hab. C. 1) temporarily exceeded $2 \mathrm{mg} \cdot \mathrm{dm}^{-3}$. 
Table 1. Selected hydrological parameters typical of the studied watercourses

\begin{tabular}{|c|c|c|c|c|c|c|}
\hline \multirow{2}{*}{ Species } & \multicolumn{2}{|c|}{ Tywa } & \multicolumn{2}{|c|}{ Rurzyca } & \multicolumn{2}{|c|}{ Kanał Habdziński } \\
\hline & 2017 & 2018 & 2017 & 2018 & 2017 & 2018 \\
\hline Bleak Alburnus alburnus & 1 & - & - & - & - & - \\
\hline European eel Anguilla anguilla & - & 1 & - & - & - & - \\
\hline Zope Ballerus ballerus & 2 & - & - & - & - & - \\
\hline Stone loach Barbatula barbatula & - & 11 & - & 1 & - & - \\
\hline White bream Blicca bjoerkna & - & - & 1 & - & - & - \\
\hline Crucian carp Carassius carassius & - & - & 1 & - & - & - \\
\hline Prussian carp Carassius gibelio & 3 & 13 & 7 & - & 6 & - \\
\hline Spined loach Cobitis taenia & 2 & - & 34 & 61 & - & - \\
\hline Pike Esox lucius & - & - & 2 & 10 & 12 & 4 \\
\hline Three-spined stickleback Gasterosteus aculeatus & 25 & 201 & - & 2 & - & - \\
\hline Gudgeon Gobio gobio & 9 & 5 & - & - & - & - \\
\hline Ruffe Gymnocephalus cernua & 8 & 6 & - & - & - & - \\
\hline Belica Leucaspius delineatus & 1 & - & - & - & 1 & - \\
\hline Common dace Leuciscus leuciscus & 5 & 1 & - & - & - & - \\
\hline Burbot Lota lota & - & 3 & - & - & - & - \\
\hline Weatherfish Misgurnus fossilis & - & 6 & 15 & 3 & 70 & 11 \\
\hline European perch Perca fluviatilis & 16 & 44 & - & - & 1 & 22 \\
\hline Amur sleeper Perccottus glenii & - & - & - & - & 51 & 52 \\
\hline Ninespine stickleback Pungitius pungitius & - & - & - & - & 1 & - \\
\hline Roach Rutilus rutilus & 19 & 26 & 62 & 302 & - & 2 \\
\hline Rudd Scardinius erythrophthalmus & - & - & - & - & - & 2 \\
\hline Chub Squalius cephalus & 10 & 27 & - & - & - & - \\
\hline Tench Tinca tinca & 1 & - & 23 & 3 & 3 & - \\
\hline The number of fish & 102 & 344 & 145 & 382 & 145 & 93 \\
\hline Number of species & 13 & 12 & 8 & 7 & 8 & 6 \\
\hline
\end{tabular}

$1-\%$ of sedimentation

${ }^{2}-\%$ macrophyte overgrowth of the surface of water

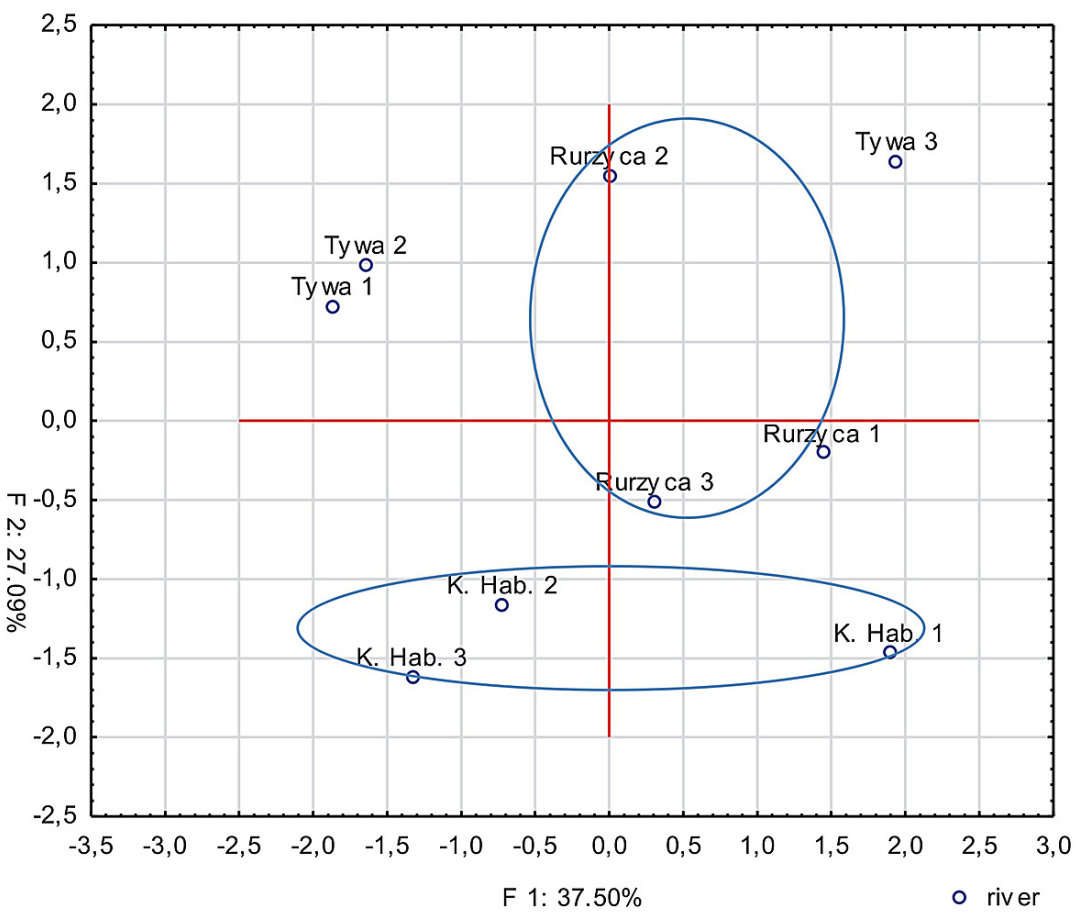

Fig. 2. PCA of factor cases 
The physicochemical data for each research site affected by the maintenance works (Table 2) demonstrated a slight increase in $\mathrm{pH}, \mathrm{EC}$ and $\mathrm{N}-\mathrm{NO}_{3}{ }^{-}$at 5 out of 9 research sites and a significant increase in the concentration of oxygen at most research sites after silt removal. Moreover, in the case of $\mathrm{N}-\mathrm{NH}_{4}{ }^{+}$and $\mathrm{P}-\mathrm{PO}_{4}{ }^{3-}$ concentrations, the maintenance works caused an increase in $\mathrm{N}-\mathrm{NH}_{4}{ }^{+}$at eight sites and in $\mathrm{P}-\mathrm{PO}_{4}{ }^{3-}$ at six out of nine sites.

The PCA, the results of which are presented in Figure 3, and the correlation values in Table 3 (mean values from years 2017 and 2018 were taken into consideration) demonstrated that some physicochemical properties of water in the rivers are correlated with each other (e.g. strongly negatively correlated EC and water concentration of oxygen) and with the number of fish and species observed in the rivers (e.g. the concentration of $\mathrm{P}_{-} \mathrm{PO}_{4}^{3-}$ i N-NH${ }_{4}^{+}$affected the number of fish species in the rivers).

\section{Changes in the number of fish and fish species resulting from maintenance works}

Electrical fishing conducted in 2017 and 2018 (i.e. before and after maintenance works) demonstrated a statistically significant increase in the number of fish in the studied watercourses, except for the Kanał Habdziński (Table 4). This appears to have resulted from almost a tenfold increase in the quantity of the three-spined stickleback (the Tywa River) and a fivefold increase in the quantity of the roach (the Rurzyca River). Moreover, due to the changes in the habitats of fish, a small decrease in the number of species was observed in every studied watercourse.

Partially protected species in Poland (Regulation of the Environment Minister of 16 December, 2016 concerning animal protection) are given in bold type.

Three partially protected species in Poland (Regulation of the Environment Minister of 16

Table 2. Studied physicochemical properties of water in each watercourse

\begin{tabular}{|l|c|c|c|c|c|c|c|c|c|c|}
\hline \multicolumn{2}{|c|}{ Specification } & \begin{tabular}{c} 
Tywa \\
\multicolumn{2}{|c|}{}
\end{tabular} & $\begin{array}{c}\text { Tywa } \\
2\end{array}$ & $\begin{array}{c}\text { Tywa } \\
3\end{array}$ & $\begin{array}{c}\text { Rurzyca } \\
1\end{array}$ & $\begin{array}{c}\text { Rurzyca } \\
2\end{array}$ & $\begin{array}{c}\text { Rurzyca } \\
3\end{array}$ & $\begin{array}{c}\text { K Hab. } \\
1\end{array}$ & $\begin{array}{c}\text { K Hab. } \\
2\end{array}$ & $\begin{array}{c}\text { K Hab. } \\
3\end{array}$ \\
\hline \multirow{2}{*}{ Water flow (m/s) } & 2017 & 0.26 & 0.65 & 0.01 & 0.14 & 0.64 & 0.15 & 0.03 & 0.08 & 0.02 \\
\cline { 2 - 12 } & 2018 & 0.85 & 0.68 & 0.18 & 0.64 & 0.81 & 0.58 & 0.07 & 0.11 & 0.03 \\
\hline \multirow{3}{*}{ Depth (cm) } & 2017 & 100 & 90 & 100 & 80 & 110 & 60 & 57 & 59 & 24 \\
\cline { 2 - 12 } & 2018 & 75 & 25 & 75 & 40 & 45 & 75 & 54 & 40 & 45 \\
\hline \multirow{2}{*}{ Layer of silt (\%) } & 2017 & 20 & 20 & 40 & 20 & 70 & 75 & 100 & 100 & 100 \\
\cline { 2 - 11 } & 2018 & 10 & 20 & 10 & 0 & 10 & 30 & 90 & 80 & 60 \\
\hline $\begin{array}{l}\text { Macrophytes } \\
(\%)\end{array}$ & 2017 & 80 & 25 & 100 & 20 & 15 & 60 & 90 & 80 & 90 \\
\cline { 2 - 11 }$y$
\end{tabular}

Table 3. Presentation of correlations between the studied physicochemical parameters of water in the rivers and the number of fish and fish species.

\begin{tabular}{|c|c|c|c|c|c|c|c|c|c|c|}
\hline Parameter & Year & Tywa 1 & Tywa 2 & Tywa 3 & $\begin{array}{c}\text { Rurzyca } \\
1 \\
\end{array}$ & $\begin{array}{c}\text { Rurzyca } \\
2 \\
\end{array}$ & $\begin{array}{c}\text { Rurzyca } \\
3 \\
\end{array}$ & K Hab. 1 & K Hab. 2 & K Hab. 3 \\
\hline \multirow{2}{*}{$\begin{array}{l}\text { Temperature } \\
{ }^{\circ} \mathrm{C}\end{array}$} & 2017 & 21.2 & 21.2 & 19.3 & 22.4 & 22.7 & 23 & 19.5 & 19.2 & 19.4 \\
\hline & 2018 & 17.9 & 21 & 19.6 & 18.9 & 18.8 & 18.3 & 23.2 & 22.1 & 17.9 \\
\hline \multirow{2}{*}{$\mathrm{pH}$} & 2017 & 7.69 & 7.68 & 7.61 & 7.51 & 7.7 & 7.72 & 7.05 & 7.11 & 7.11 \\
\hline & 2018 & 7.77 & 7.93 & 7.48 & 7.35 & 7.3 & 7.07 & 7.32 & 7.28 & 6.67 \\
\hline \multirow{2}{*}{$\begin{array}{l}\text { EC } \\
{[\mu \mathrm{s} / \mathrm{cm}]}\end{array}$} & 2017 & 606 & 598 & 881 & 629 & 620 & 540 & 698 & 636 & 645 \\
\hline & 2018 & 614 & 514 & 809 & 661 & 816 & 897 & 566 & 585 & 488 \\
\hline \multirow{2}{*}{$\begin{array}{l}\mathrm{O}_{2} \\
{\left[\mathrm{mg} \cdot \mathrm{dm}^{-3}\right]}\end{array}$} & 2017 & 4.45 & 3.45 & 2.11 & 4.56 & 3.83 & 2.32 & 2.19 & 2.66 & 3.19 \\
\hline & 2018 & 6.23 & 6.62 & 3.16 & 3.68 & 6.04 & 4.30 & 3.95 & 4.97 & 4.76 \\
\hline \multirow{2}{*}{$\begin{array}{l}\mathrm{N}-\mathrm{NO}_{3}^{-} \\
{\left[\mathrm{mg} \cdot \mathrm{dm}^{-3}\right]}\end{array}$} & 2017 & 4.90 & 5.26 & 11.93 & 4.27 & 3.57 & 0.29 & 7.50 & 6.67 & 6.72 \\
\hline & 2018 & 4.02 & 5.42 & 2.06 & 7.24 & 9.81 & 7.62 & 3.16 & 2.02 & 2.54 \\
\hline \multirow{2}{*}{$\begin{array}{l}\mathrm{N}-\mathrm{NH}_{4}^{+} \\
{\left[\mathrm{mg} \cdot \mathrm{dm}^{-3}\right]}\end{array}$} & 2017 & 0.08 & 0.09 & 0.08 & 0.14 & 0.12 & 0.13 & 0.16 & 0.73 & 0.07 \\
\hline & 2018 & 0.11 & 0.14 & 0.81 & 2.02 & 0.41 & 0.35 & 2.62 & 0.21 & 0.09 \\
\hline \multirow{2}{*}{$\begin{array}{l}\mathrm{P}-\mathrm{PO}_{4}{ }^{3-} \\
{\left[\mathrm{mg} \cdot \mathrm{dm}^{-3}\right]}\end{array}$} & 2017 & 0.46 & 0.68 & 0.50 & 0.72 & 0.99 & 0.72 & 0.64 & 0.82 & 0.70 \\
\hline & 2018 & 1.20 & 1.05 & 0.87 & 3.22 & 0.95 & 2.11 & 2.37 & 0.14 & 0.02 \\
\hline
\end{tabular}




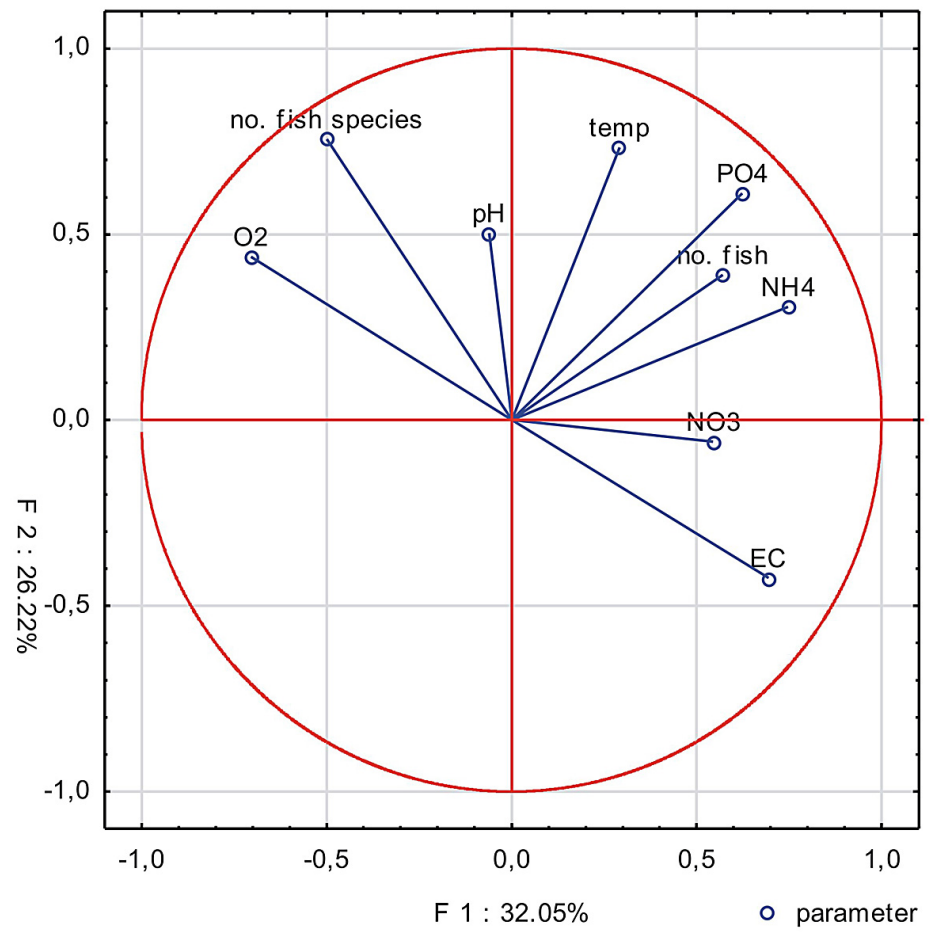

Fig. 3. Position of vectors of physicochemical properties and number of fish and fish species in the rivers against the two main components

Table 4. The number of fish and fish species in each watercourse

\begin{tabular}{|c|c|c|c|c|c|c|c|c|c|}
\hline \multirow{2}{*}{ Variable } & \multicolumn{9}{|c|}{ Correlations (summary) } \\
\hline & temp & $\mathrm{pH}$ & $\mathrm{EC}$ & $\mathrm{O}_{2}$ & $\mathrm{~N}-\mathrm{NO}_{3}^{-}$ & $\mathrm{N}-\mathrm{NH}_{4}^{+}$ & $\mathrm{P}_{-} \mathrm{PO}_{4}{ }^{3-}$ & $\mathrm{N} \mathrm{FISH}$ & N SPEC. \\
\hline Temp & 1.000 & 0.271 & -0.082 & 0.030 & 0.045 & $0.503^{*}$ & $0.580^{*}$ & 0.105 & 0.354 \\
\hline $\mathrm{pH}$ & 0.271 & 1.000 & 0.180 & $0.474^{*}$ & 0.281 & -0.255 & 0.159 & 0.226 & 0.347 \\
\hline EC & -0.083 & 0.180 & 1.000 & $-0.553^{*}$ & $0.592^{*}$ & 0.080 & 0.116 & 0.263 & $-0.699^{*}$ \\
\hline $\mathrm{O}_{2}$ & 0.030 & 0.474 & $-0.553^{*}$ & 1.000 & -0.120 & -0.474 & -0.127 & -0.262 & $0.553^{*}$ \\
\hline $\mathrm{N}-\mathrm{NO}_{3}^{-}$ & 0.045 & 0.281 & $0.592^{*}$ & -0.120 & 1.000 & 0.217 & 0.089 & 0.326 & -0.260 \\
\hline $\mathrm{N}-\mathrm{NH}_{4}^{+}$ & $0.503^{*}$ & -0.255 & 0.080 & -0.474 & 0.217 & 1.000 & $0.685^{*}$ & 0.382 & -0.184 \\
\hline $\mathrm{P}_{-} \mathrm{PO}_{4}^{3-}$ & $0.580^{*}$ & 0.159 & 0.116 & -0.127 & 0.089 & $0.685^{*}$ & 1.000 & $0.524^{*}$ & 0.028 \\
\hline $\mathrm{N} \mathrm{FISH}$ & 0.105 & 0.226 & 0.263 & -0.262 & 0.326 & 0.382 & $0.524^{*}$ & 1.000 & 0.199 \\
\hline N SPEC. & 0.354 & 0.347 & $-0.699^{*}$ & $0.553^{*}$ & -0.260 & -0.184 & 0.028 & 0.199 & 1.000 \\
\hline
\end{tabular}

* Statistically significant correlations at $\mathrm{p}>0.05$ are presented

${ }^{1}-\chi^{2}$ test results for the number of fish: The Tywa River $\chi^{2}=131.31, \mathrm{p}=0.00001$, the Rurzyca River $\chi^{2}=106.58$, $\mathrm{p}=0.00001$, the Kanał Habdziński $\chi 2=11.36, \mathrm{p}=0.00075$

${ }^{2}-\chi^{2}$ test results for the number of fish species: The Tywa River $\chi^{2}=0.04, \mathrm{p}=0.84118$, the Rurzyca River $\chi^{2}=$ $0.0666, p=0.79625$, the Kanał Habdzinski $\chi 2=0.2857, p=0.592980$

December, 2016 concerning animal protection) were observed in the catch: the spined loach, the weatherfish and the stone loach. The first two species are also included in Annex II of the Habitats Directive (Directive 92/43/EEC). Interestingly, the stone loach was only observed in the catch after the maintenance works, which is a likely consequence of the changes in the water environment and improvement of habitats for this particular fish species. In the case of the weatherfish, its population decreased after the maintenance works in two rivers, whereas in the case of the spined loach, the species had disappeared at one site, but at another site its population had doubled.

It is also worth noting that in the Kanal Habdziński, the population of the invasive species, i.e. Amur sleeper, neither disappeared nor changed despite the maintenance works. This indicates its high endurance, good adaptation to variable environmental conditions and, according to the relevant literature, rapid population recovery (Rechulicz et al., 2015). 
In natural flowing waters, dredging is normally treated as a procedure leading to irreversible changes in the environment resulting from removal of all organisms, including invertebrates, connected with the riverbed and water plants (Aldridge 2000). On the other hand, dredging might have a positive effect on other taxa. In the case of water beetles on a small regulated lowland river, rapid recovery of the species was observed and, after dredging, higher biodiversity and a greater content of rheophilic species were noted in comparison to the previous state (Dąbkowski et al., 2016). According to Płaska et al. (2016), silt removal has no significant effect on the Heteroptera diversity, but causes an increase in the population size. The authors note that dredging caused an increase in the number of available habitats which were mainly occupied by numerous pioneer species.

It is common knowledge that the maintenance works in watercourses of agricultural areas and flood plains cause the occurrence of new habitats of plants and animals (Mazerolle 2006; Davies et al., 2008). Numerous scientific reports concerning the effect of dredging and silt removal concern firmly-bonded organisms or organisms with limited ability to travel in the ecosystem (Kaenel and Uehlinger 1998; Rehitha et al., 2017; Ochs et al., 2018). Fish are more or less bound to the riverbed where they can reside, feed or reproduce. Still, relatively little is known about the effect of dredging on the populations of this group of vertebrates. According to Desprez (2000), fish are less susceptible to the effects of dredging than the benthic zone organisms, for example, due to their ability to escape to upper or lower sections of the watercourse. However, there are species that prefer the benthic zones as a place for living and reproduction; for those species, the changes in their environment resulting from maintenance works will have a significant impact (Westerberg et al., 1996). Sediment removal is also connected with a loss of spawning grounds and habitats for juvenile individuals. Moreover, many benthic zone fish might be affected by the removal of benthos, which is a crucial source of feed (Jurajda et al., 2007). A theory says that maintenance works might cause better feed availability in habitats resulting from the exposure of resource in silted watercourses (Pérez-Ruzafa et al., 2006). During the monitoring, we observed new species in some habitats, in comparison to year 2017 and even an increase in the number of fish in the Tywa River and the Rurzyca River. It is believed that during maintenance works, part of less sensitive fish travel small distances to return to their previous habitats after a short time (Da Silva Junior et al., 2012). The possible causes of the phenomenon could be the climatic changes between the studied years, habitat preferences of each fish species and the duration of spontaneous self-restoration of watercourses, which might be irregular depending on many factors.

Small watercourses in rural areas are often intensively overgrown with macrophytes and the riverbed is covered with a significant layer of silt as a result of intensification of agricultural works. In times of increased water levels in rural watercourses, their drainage through dredging very often protects farmlands against flooding. However, it has to be remembered that those small ecosystems contain habitats of native fish populations and other living organisms. Dredging and sediment removal from ecosystems of small rivers is crucial and should be conducted with proper care due to the presence of the species that are economically important and endangered with excessive exploitation.

\section{CONCLUSIONS}

The selected watercourses were characterised by low water quality, mainly biogenic substances, which was related to their location in agricultural reception areas. Inventories of ichthyofauna in each watercourse demonstrated a small number of fish species, among which there were three partially protected species in Poland (the spined loach, the weatherfish and the stone loach) and one invasive species (the Amur sleeper). The studies conducted before and after the maintenance works, including removal of silt and water plants, demonstrated a significant negative effect of such procedures on the chemical quality of waters in the studied watercourses. Despite a small decline in the number of species after the maintenance works, a statistically significant increase in the size of fish populations was observed in the Tywa River and the Rurzyca River. It is probably connected with the fact that some fish that are less sensitive to the changes in water quality travel short distances during the maintenance works in order to return to their habitats, while others might appear in these habitats as a result of changes in the habitats. The most sensitive species might disappear due to the direct effect of the works or because of the disappearance of their typical habitats and spawning grounds. 


\section{Acknowledgements}

The research financed under the multiannual program by the Institute of Technology and Life Sciences and entitled "Engineering and landscaping projects for innovative, resource-efficient and low-carbon economy in rural areas", Activity 5 "Information support for preparation, completion and acceptance of land improvement equipment" (154/2016_RM-111-156-16).

\section{REFERENCES}

1. Aldridge D.C. 2000. The impacts of dredging and weed cutting on a population of freshwater mussels (Bivalvia: Unionidae). Biological Conservation, 95, 247-257.

2. Bondar-Nowakowska E., Hachoł J. 2015. Ecological risk assessment in the regulated watercourses. Journal of Ecological Engineering, 16 (5), 183-189.

3. Cavailléa P., Dommangeta F., Daumerguea N., Loucougaraya G., Spiegelbergera T., Tabacchib E., Evettea A. 2013. Biodiversity assessment following a naturality gradient of riverbank protection structures in French prealps rivers. Ecological Engineering, 53, 23-30.

4. Davies B., Biggs J., Williams P., Whitfield M., Nicolet P., Sear D., Bray S., Maund S. 2008. Comparative biodiversity of aquatic habitats in the European agriculturallandscape. Agriculture, Ecosystems \& Environment, 125, 1-8.

5. Dąbkowski P., Buczyński P., Zawal A., Stepien E., Buczynska E., Stryjecki R., Czachorowski S., Smietana P., Szenejko M. 2016. The impact of dredging of a small lowland river on aquatic beetle fauna (Coleoptera). Journal of Limnology, 75, 472-487.

6. Desprez M. 2000. Physical and biological impact of marine aggregate extraction along the French coast of the Eastern English Channel: short- and long-term post-dredging restoration. ICES Journal of Marine Science, 57, 1428-1438.

7. Haidekker A., Hering D. 2008. Relationship between benthic insects (Ephemeroptera, Plecoptera, Coleoptera, Trichoptera) and temperature in small and medium-sized streams in Germany: a multivariate study. Aquatic Ecology, 42 (3),463-481

8. Da Silva Junior D.R., Santos S.R., Travassos M., Vianna M. 2012. Impact on a fish assemblage of the maintenance dredging of a navigation channel in a tropical coastal ecosystem. Brazilian Journal Of Oceanography, 60 (1), 25-32.

9. Jurajda P., Adámek Z., Janáč M., Valová Z. 2007. Fish and macrozoobenthos in the Vlára stream drainage area (Bílé Karpaty Mountains). Czech Journal of Animal Science, 52 (7), 214-225.

10. Kaenel B.R., Uehlinger U. 1998. Effects of plant cutting and dredging on habitat conditions in streams. Archiv fur Hydrobiologie, 143 (3), 257-273.
11. Kaznowska E. 2012. Wieloletnie tendencje w kształtowaniu się wybranych charakterystyk niżówek w zlewni rzeki Zagożdżonki. Infrastruktura i Ekologia Terenów Wiejskich, 3 (IV), 215-227.

12. Louhi P., Mäki-Petäys A., Erkinaro J., Paasivaara A., Muotka T. 2010. Impacts of forest drainage improvement on stream biota: a multisite BACI-experiment. Forest Ecology and Management, 260, 1315-1323.

13. Luek A., Rasmussen J.B. 2017. Chemical, physical, and biological factors shape littoral invertebrate community structure in coal-mining end-pit lakes. Environmental Management, 59 (4), 652-664.

14. Mazerolle M. J. 2006. Drainage ditches facilitate frog movements in a hostile land-scape. Landscape Ecology, 20, 579-590.

15. Montgomery F.A., Reid S.M., Mandrak N.E. 2018. A habitat-based framework to predict the effects of agricultural drain maintenance on imperiled fishes. Journal of Environmental Management, 206, 1104-1114.

16. Ochs K., Rivaes R.P., Ferreira T., Egge G. 2018. Flow management to control excessive growth of macrophytes - an assessment based on habitat suitability modeling. Frontiers in Plant Science, 9, 356-367.

17. Pérez-Ruzafa A., García-Charton J.A., Barcala E., Marcos C. 2006. Changes in benthic assemblages as a consequence of coastal works in a coastal lagoon: The Mar Menor (Spain, Western Mediterranean). Marine Pollution Bulletin, 53, 107-120.

18. Płaska W., Kurzątkowska A., Stępień E., Buczyńska E., Pakulnicka J., Szlauer-Łukaszewska A., Zawal A. 2016. The effect of dredging of a small lowland river on aquatic Heteroptera. Annales Zoologici Fennici, 53 (3-4), 139-153.

19. Rechulicz J., Płaska W., Nawrot D. 2015. Occurrence, dispersion and habitat preferences of Amur sleeper (Perccottus glenii) in oxbow lakes of a large river and its tributary. Aquatic Ecology, 49 (3), 389-399.

20. Rehitha T.V., Ullas N., Vineetha G., Benny P.Y., Madhu N.V., Revichandran C. 2017. Impact of maintenance dredging on macrobenthic community structure of a tropical estuary. Ocean \& Coastal Management, 144, 71-82.

21. Stammler K.L., McLaughlin R.L., Mandrak N.E. 2008. Streams modified fordrainage provide fish habitat in agricultural areas. Canadian Journal of Fisheries and Aquatic Sciences, 65, 509-522.

22. Ward-Campbell B., Cottenie K., Mandrak N.E., McLaughlin R.L. 2017. Fish assemblages in agricultural drains are resilient to habitat change caused by drain maintenance. Canadian Journal of Fisheries and Aquatic Sciences, 74 (10), 1538-1548.

23. Westerberg H., Ronnback P., Frimansson H. 1996. Effects of suspended sediments on cod eggs and larvae and on the behaviour of adult herring and cod. ICES Council Meeting Papers, 26, 1-13.

24. Wojciechowska E., Nawrot N., Matej-Łukowicz K., Gajewska M., Obarska-Pempkowiak H. 2019. Seasonal changes of the concentrations of mineral forms of nitrogen and phosphorus in watercourses in the agricultural catchment area (Bay of Puck, Baltic Sea, Poland). Water Supply, 19 (3), 986-994. 